\title{
PLANKTON PRODUCTION OFF PLYMOUTH AND THE MOUTH OF THE ENGLISH CHANNEL IN I939
}

\author{
By Molly F. Mare, B.A. \\ Newnham College, Cambridge
}

(Text-figs. I-IO)

\section{INTRODUCTION}

Regular quantitative samples of phytoplankton and small zooplankton were taken near Plymouth with the Harvey measuring net from January to August 1939. Similar samples were obtained on three cruises ${ }^{\star}$ from the area comprising the western entrance of the English Channel and south of Ireland as far as the edge of the continental shelf. The microplankton of this area as a whole has been little investigated, the only previous quantitative records being those of Ogilvie (1923). The seasonal survey at Plymouth, though from inshore stations, forms a useful basis for comparison with the regional observations from the south-western area, and together they extend part of the work carried out in 1934 by Harvey et al. (1935) on plankton production and its control. The results in this paper deal only with phytoplankton in detail, and briefly with zooplankton in so far as it is necessary to the discussion of grazing intensity and for comparison with the results of 1934. Tables giving full details of the numerical data on which the following is based have been deposited for reference in the Library of the Marine Biological Association at Plymouth.

Papers by Cleve (1900), Gough (1905-7), Bygrave (I9II), Bullen (I908), Lebour (1917) and records and résumés in the Bulletin Planktonique deal with the phytoplankton in this area.

\section{MetHods}

Vertical hauls were made with the Harvey measuring net (Harvey, 1934) at $\mathrm{L}_{4}$, the station used in the 1934 survey, 5 miles seaward of the Plymouth Breakwater lighthouse, and some hauls were also made at a slightly shallower station I mile west-south-west of Rame Head. At both stations hauls were made between the surface and $40 \mathrm{~m}$. (that is to within 5-10 $\mathrm{m}$. of the bottom); a measured quantity of water usually about I cu. $\mathrm{m}$. passed through the net. The bolting silk (200 meshes to the inch) had an average pore size of $52 \times 40 \mu$ when wet. After addition of formalin the catch was made up to 500 c.c. and

* Cruises made in connexion with mackerel researches at Plymouth. 
further diluted if necessary. The phytoplankton was allowed to settle in a cell $\mathrm{I} \cdot 75 \mathrm{~mm}$. deep and counted from a total volume varying between 0.070 and 0.232 c.c. of the catch; the zooplankton and faecal pellets were counted in 3-5 aliquot subsamples of 4 c.c. each. This gave a sufficient order of accuracy as the exact numbers of rare species are not of particular interest. A proportion of the smaller organisms will of course have passed through the net, therefore the numbers given are minimal. While these methods do not give a complete picture of the microplankton, it is thought worth while to present the results obtained as they probably indicate the main trends of production in the area.

On the cruises the same Harvey net was used as at Plymouth. The catch was made up to 500 c.c., a small subsample (I/I Ith of the whole) was fixed and retained for species counts, and the rest filtered and an acetone extract made of the plant pigments (Harvey, 1934). In April and June the hauls were made between the surface and 20 fathoms (i.e. to approximately the same depth as those at $\mathrm{L}_{4}$ and Rame). On the March cruise at each of the five stations they were taken to 40 fathoms; but as it was found at St. 2 that all the phytoplankton was in the upper 20 fathoms, the meter readings were halved, thus making the figures more comparable with the others given in the tables: the phytoplankton was in any case very sparse and the general picture from that cruise remains unaltered. Counts were made as above, except that when very sparse in March and June some of the phytoplankton had to be counted in 4 c.c. subsamples. Nomenclature in this paper is that used by Lebour (1925, I930) and Kofoid \& Campbell (I929). Synonyms found in other lists referring to the south-western area are shown in parentheses.

\section{Seasonal Survey at Plymouth}

As pointed out by Harvey et al. (1935) there is movement of water masses at $\mathrm{L}_{4}$, but it is probably correct to assume that water occupying that position at the time of sampling has passed through a history similar to that previously sampled. Plankton at the Rame station was very similar to that at $\mathrm{L}_{4}$, therefore on the whole the series of samples may be accepted as a reliable indication, both qualitatively and quantitatively, of planktonic successions in the neighbourhood of these two stations. Nevertheless, some of the fluctuations in numbers of animals (see Fig. 2), particularly in February and March, may be correlated with changes in water masses and not much significance should be attached to them.

It will be seen from Fig. I that in the early part of 1939 the phytoplankton at $\mathrm{L}_{4}$ was very sparse. At the end of February a centric diatom, $4-8 \mu$ in diameter and probably Thalassiosira nana, was found abundantly, mainly adhering to other chains; much of this will also have been lost through the net. There was some increase in numbers during March, particularly of Chaetoceros decipiens followed by $C$. debilis, C. affinis and C. laciniosus. The maximum was late, the highest figures being 27,000 cells per litre recorded 
at $\mathrm{L}_{4}$ on April I2 and 93,000 cells per litre at Rame on April I4: C. debilis was dominant and among a rich variety of species Thalassiosira Nordenskioldii, T. gravida, Coscinoscira polychorda, Thalassiothrix Nitzschioides, Lauderia borealis and other Chaetoceros species were abundant. After these dates there was a gap in the observations until the end of the month while the net was-in use on the second cruise. The subsequent smaller peaks in the numbers

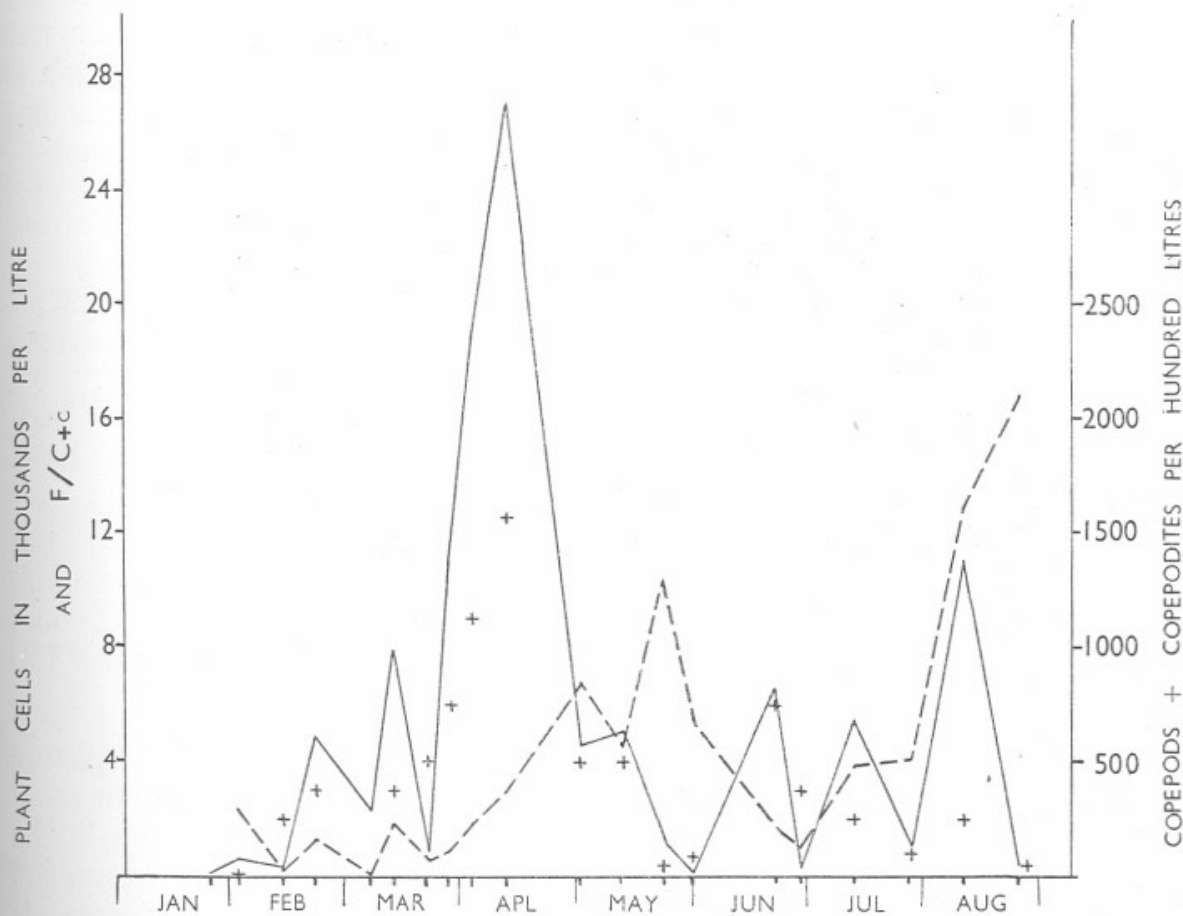

Fig. I. Seasonal changes at $\mathrm{L}_{4}$, near Plymouth, in 1939. Numbers of plant cells, in thousands per litre (continuous line), numbers of copepods plus copepodites per I00 1 . of sea (broken line) and number of faecal pellets per copepod plus copepodites, $F / C+c(+)$. This ratio shows correlation with the numbers of plant cells; the value for March 6 is anomalous - 170 -and is omitted from the graph. Lines joining the points have no real meaning.

mainly consisted of small-celled species: Rhizosolenia delicatula in May, $R$. Stolterfothii with Guinardia flaccida in June, Sceletonema costatum and Ceratium fusus in July and Rhizosolenia alata, $R$. delicatula, $R$. Stolterfothii and Nitzschia delicatissima in August. In I934 phytoplankton was abundant during the first two months and the highest density, in units of plant pigment, was recorded on March 20 (numbers were actually highest on the 26th, but this was due to a dense outburst of Sceletonema costatum). A comparison of the distribution of the hours of sunshine in the two years (the only comparable light data yet available, obtained from the Plymouth meteorological records) 
suggests that light intensity may be one of many factors responsible for these differences. In I934 January and February were very bright while March and April were rather dull. In 1939 the hours of sunshine for the first two months differed little from the mean for the past 40 years. The first part of March was very dull, bringing the total hours of sunshine for the month much below average; the latter part of March and the whole of April were bright. An apparent lag after the brightening of the weather before the phytoplankton maximum is reached has been previously recorded in this region (Atkins, I930). The differences in the quantities of phytoplankton as shown by monthly averages of cell numbers are given in Table I, the I934 figures being taken from the paper mentioned above (Harvey et al. 1935).

\section{Table I. Monthly Averages}

\begin{tabular}{|c|c|c|c|c|c|c|c|c|c|}
\hline & \multicolumn{3}{|c|}{ Plant cells per litre } & \multicolumn{3}{|c|}{$\begin{array}{l}\text { Copepods + copepodites } \\
\text { per roo } 1 \text {. }\end{array}$} & \multicolumn{3}{|c|}{ Total animals per 1001.} \\
\hline & \multirow[b]{2}{*}{$\begin{array}{c}\mathrm{I} 934 \\
\mathrm{~L} 4\end{array}$} & \multicolumn{2}{|c|}{ I939 } & \multirow{2}{*}{$\begin{array}{l}\mathrm{I} 934 \\
\mathrm{~L} 4\end{array}$} & \multicolumn{2}{|c|}{ I939 } & \multirow{2}{*}{$\begin{array}{l}\mathrm{I} 934 \\
\mathrm{~L} 4\end{array}$} & \multicolumn{2}{|c|}{ I939 } \\
\hline & & $\mathrm{L}_{4}$ & Rame & & $\mathrm{L}_{4}$ & Rame & & $\mathrm{L}_{4}$ & Rame \\
\hline Jan. & 2380 & 64 & 260 & $7 \mathrm{I}$ & $\ldots$ & $\ldots$ & 239 & & 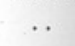 \\
\hline Feb: & I 750 & I940 & & II9 & I59 & .. & 545 & 580 & \\
\hline Mar. & 21600 & 5430 & I 850 & 318 & 106 & 39 & 2024 & 640 & 380 \\
\hline Apr. & 3890 & 22900 & 56900 & 450 & 295 & 277 & 2518 & I990 & 2390 \\
\hline May & 7100 & 2750 & 5300 & 1028 & 850 & 797 & 3365 & 3590 & 1640 \\
\hline June & 6050 & 3490 & 5740 & 439 & I75 & 270 & 2440 & I380 & II 40 \\
\hline July & 2320 & 3220 & 520 & 799 & 500 & 380 & 2852 & 2880 & 1900 \\
\hline Aug. & 740 & 5920 & $\ldots$ & I343 & 1030 & .. & 4963 & 6530 & \\
\hline
\end{tabular}

The Harvey net used in collecting these samples is too small to give a picture of the total population of zooplankton, but it is worth while to count those animals which were caught so as to gain an idea of the variations in the population of herbivores. These include both diatom eaters and consumers of nannoplankton. On the whole it would appear that the number of copepods plus copepodites caught is proportional to the total diatom grazing population. In working up data collected with the same apparatus, Harvey used the number of faecal pellets per copepod plus copepodite as an index of the amount of grazing per animal. This ratio $(F / C+c)$, the number of plant cells per litre (unweighted for size) and the number of copepods plus copepodites per 1001 . of sea are plotted together in Fig. I. As already shown by Harvey, there is highest grazing activity at times of phytoplankton abundance (see 1935, Fig. I2, p. 424). At the spring diatom maximum the faecal pellets were green, whereas later they were brown, when probably the diet included a higher proportion of detritus. Most of the faecal pellets were too large to have been produced by the copepods caught in the net; it is therefore not surprising that there should be some anomalous results when pellets were apparently very abundant relative to the number of animals, e.g. at $\mathrm{L}_{4}$ and Rame on March 6 and 9 . 


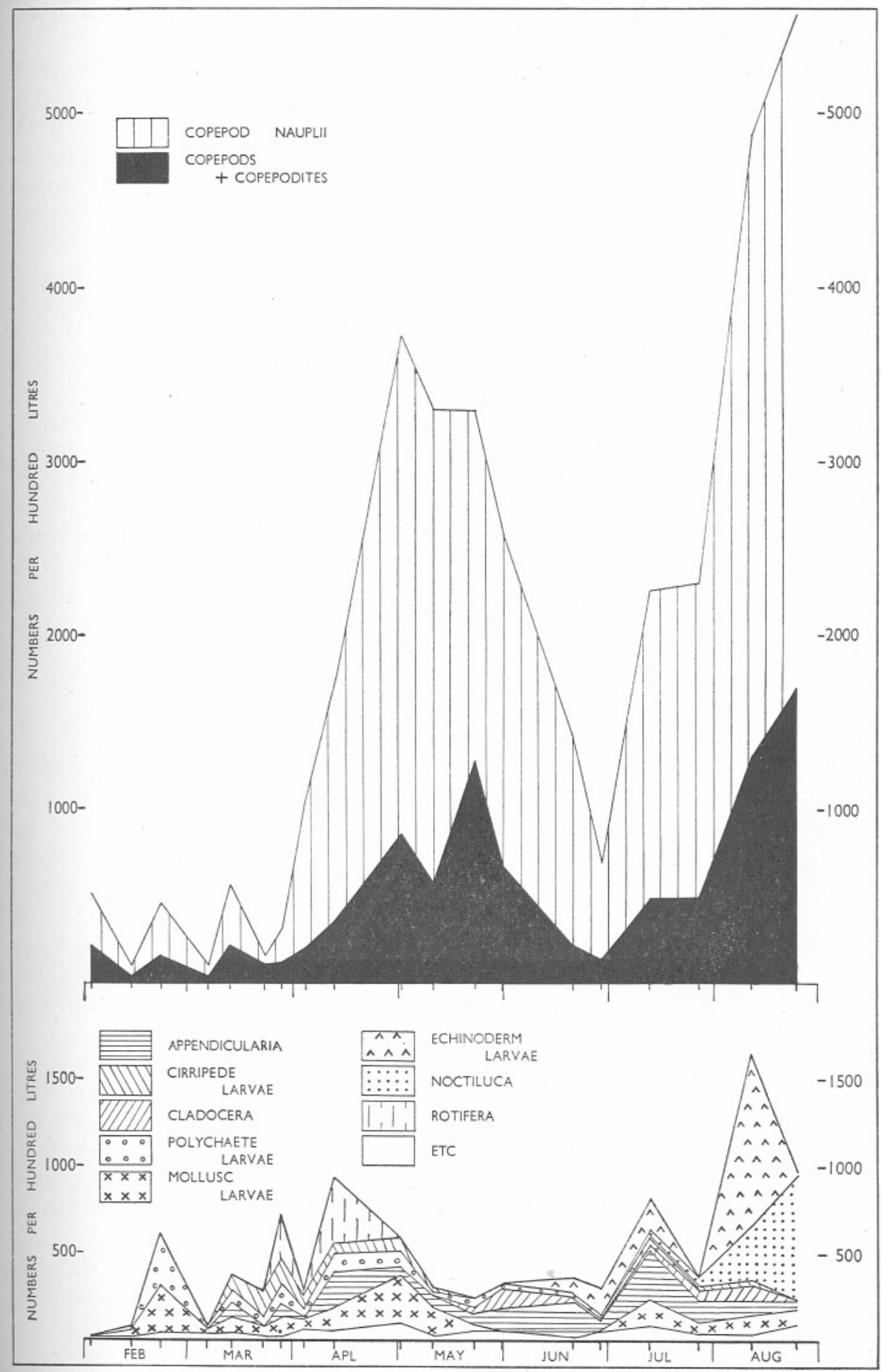

Fig. 2. Seasonal changes in the number of animals at L4, near Plymouth, in I939. 
The zooplankton numbers followed the usual course, rising after the spring phytoplankton maximum and showing reciprocal fluctuations during June and July. In the early part of the year the fluctuations were concurrent (see p. 462). The summer increase in zooplankton was still in progress when sampling had to be discontinued. The zooplankton was not identified in detail as it was required only as an indication of the abundance of animal life. Fig. 2 shows the total number of copepods with the proportion of nauplii to copepods plus copepodites, and the total of other animals and the proportions of the various groups. There is a general similarity with the I934 data (see Harvey et al. 1935, Fig. 9, p. 42I) particularly with regard to copepods and rotifers. Mollusc larvae were more numerous in 1939 but no swarm of Limacina was encountered. Numbers of echinoderm larvae were insignificant in the early part of the year and are included in the bottom group until the end of May: the outburst of ophioplutei in the latter part of the summer, though not found in 1934, has been paralleled in several previous records. Table I shows that the monthly averages of the total number of animals, including meroplanktonic forms, was of the same order in the two years; the copepods plus copepodites were, however, only about two-thirds as numerous in 1939 as in the earlier year, thus showing evidence of the general decline in quantity of zooplankton which Russell has found here since 1934 (see Russell, I938, Table II, p. 4I9, for medusae and young fish).

\section{Regional Survey of THE SOUth-Western AREA}

On the first cruise phytoplankton samples were taken at only five stations on March I5 and 16, and at all these plants were scarce. Fig. 3 A shows the density distribution in Harvey's arbitrary units of plant pigment per cubic metre, and the positions of the stations relative to the edge of the continental shelf, as indicated by the Ioo fathom line. At St. I and 2 nearly all species were neritic, while the three outer stations showed oceanic influence in the presence of Radiolaria, Globigerina, Dictyocysta lepida (an Atlantic and Mediterranean tintinnid, recorded as D. templum by Ogilvie) and the Atlantic oceanic diatom Dactylosolen antarcticus; Ceratium bucephalum and C. lamellicorne were also restricted to these stations.

The second cruise (April 16-26) presents many interesting features of distribution both of phytoplankton density as a whole and of individual species. Fig. 3 B shows the phytoplankton density in terms of Harvey's arbitrary pigment units; the highest values were 6250 at St. 20 on the edge of the continental shelf, and 4400 at St. 2 and 36 at the mouth of the English Channel. Fig. 4 shows all stations, but at only the numbered stations was full examination for species made.

Figs. 5 and 6 give examples of the types of species distribution encountered. They indicate the presence, in the top 20 fathoms, at the particular time of sampling, of organisms not rarer than approximately one per Io 1 . of sea. 

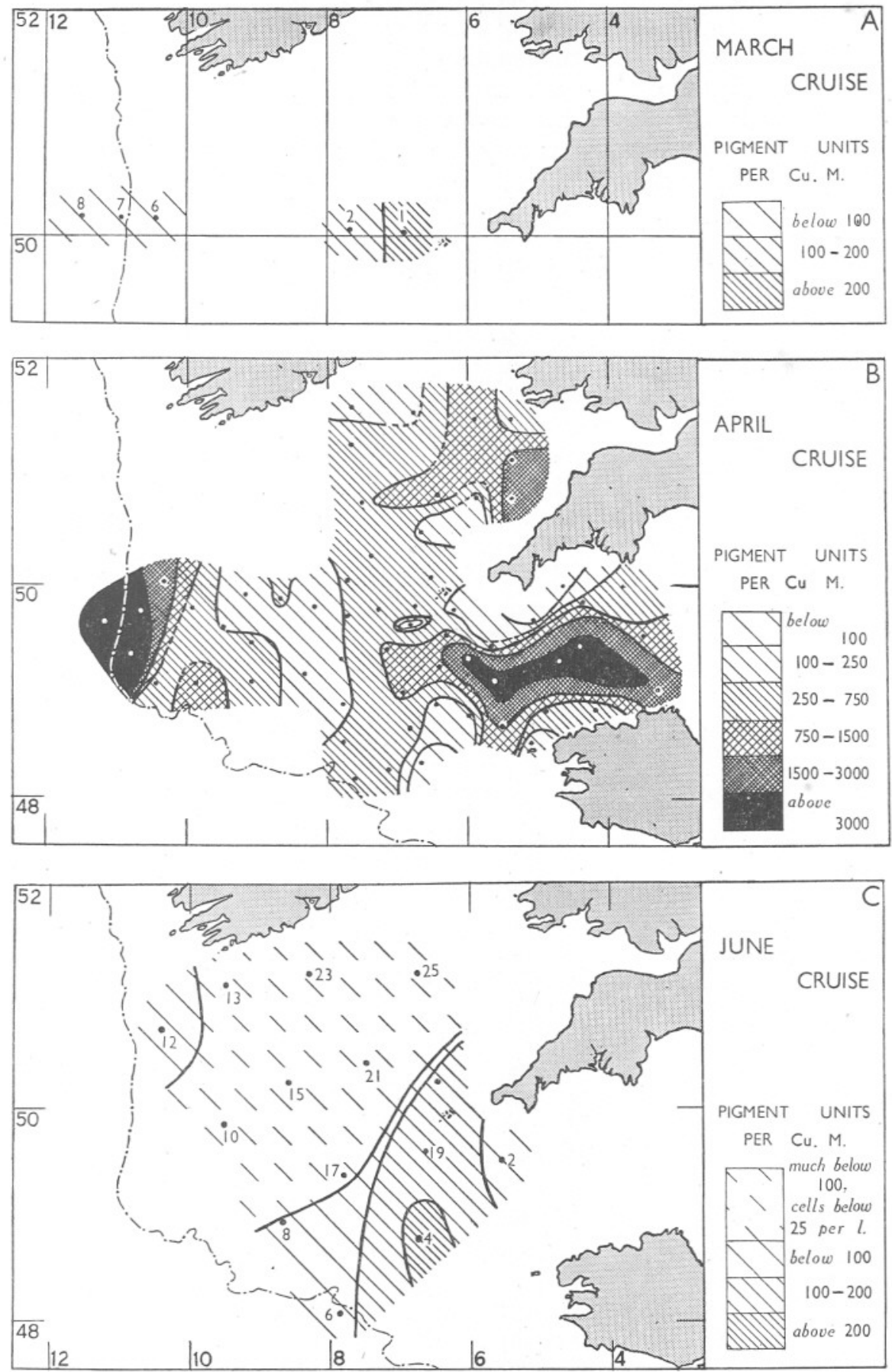

Fig. 3. Distribution of phytoplankton in Harvey's pigment units, in the south-western area in March, April and June 1939. 
Small species would not have been recorded unless considerably more abundant than this, and the absence of a species from isolated stations which showed a low total density has not been regarded as significant.

The areas of distribution as they appeared at the time of sampling may be classified as follows:

(I) A region at the mouth of the English Channel was occupied by neritic species; these showed signs of spreading west or extending north to include

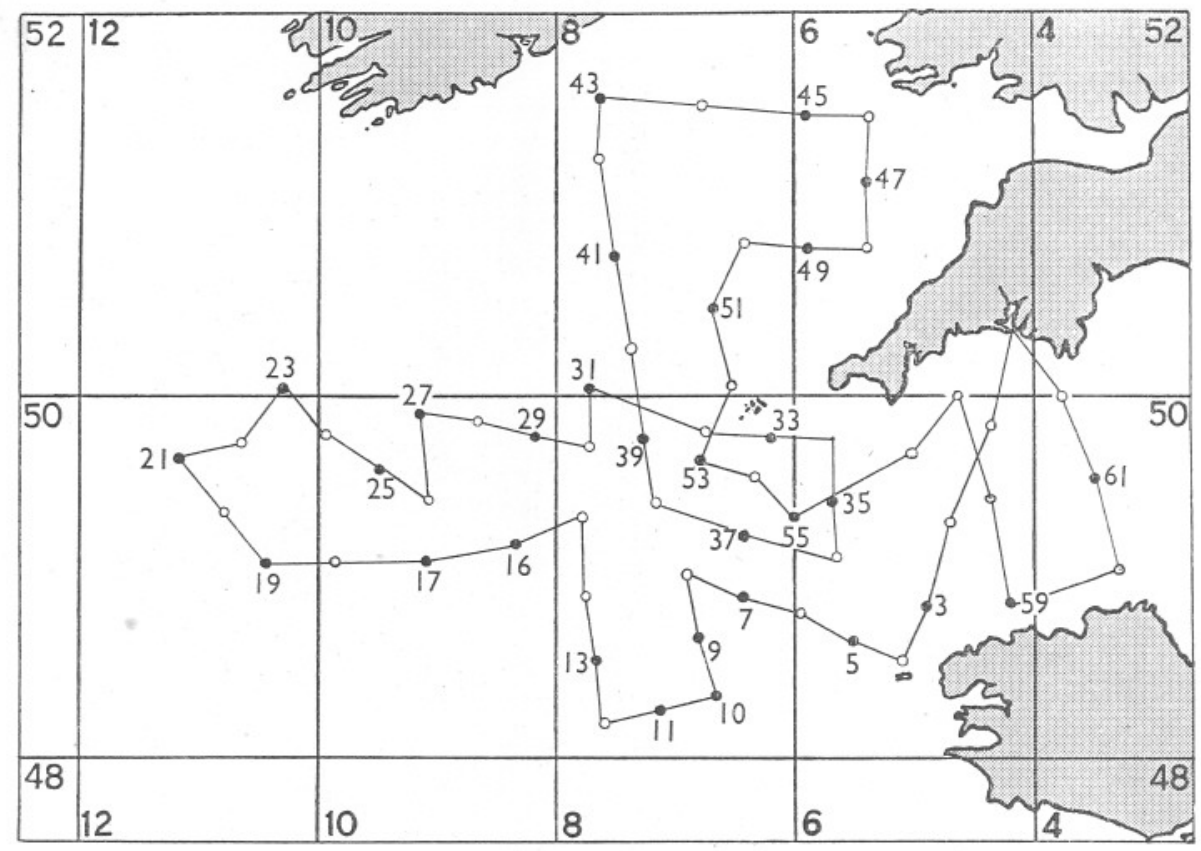

Fig. 4. April cruise. Full examination for phytoplankton was made at numbered stations; pigment extracts were made at all stations marked with a circle or spot; salinity determinations were made at all stations to St. 56 inclusive.

the area off the southern entrance to the Irish Sea, e.g. Biddulphia sinensis, Thalassiothrix Nitzschioides (with sporadic occurrences to the far west), Asterionella japonica, Ditylum Brightwelli, Phaeocystis globosa (with which was associated Nitzschia delicatissima), Lauderia borealis, Rhizosolenia Shrubsolei, $R$. Stolterfothii (in part) and Chaetoceros spp. (in part). Some of these possibly showed indications of a north-westerly current north of the Scillies (see Fig. 5).

(2) The mid-west region, approximately $8-10^{\circ} \mathrm{W}$., was occupied by Rhizosolenia delicatula. This neritic species was dominant and fairly abundant in an otherwise sparsely populated region (see Fig. 5 F). 
(3) The region farthest west, near the edge of the continental shelf, had a dense patch of Chaetoceros affinis with Guinardia flaccida (neritic species) and also Chaetoceros decipiens and other oceanic species included in the next group. Rhizosolenia Stolterfothii found there was mainly much smaller than the normal form (see Fig. $5 \mathrm{E}$ ).

(4) The west and south-west region had oceanic species which showed varying degrees of penetration towards the mouth of the English Channel, e.g. Rhizosolenia styliformis and R. alata, Ceratium bucephalum and C. lamellicorne, Globigerina and silicoflagellates (see Fig. 6 A, D, E).

(5) Near Ushant and close to the French coast were found a group of neritic species, e.g. Thalassiosira Nordenskioldii, Coscinoscira polychorda and Streptotheca thamensis (three diatoms abundant at Plymouth at the same time), Noctiluca and Tintinnopsis campanula (see Figs. 5 B, 6E).

(6) The Scilly Isles region had a mixture of oceanic and neritic forms. Fritillaria and rotifers were at that time confined to this area, while Rhizosolenia styliformis and Ceratium bucephalum occurred here as well as in the southwest (see Fig. 6 A, C, D). Rhizosolenia robusta appearing at St. 33 also occurred rarely in the south and in the Channel.

These species distributions are in reasonable agreement with previous records. Many of the species here showing only oceanic affinities have previously been recorded from the English Channel, but were not usually found far up Channel; this may be accounted for either by differences in the size of the samples examined or by the lack of penetration of oceanic water at present.

In the mouth of the English Channel Chaetoceros decipiens and C. debilis were largely responsible for the high cell numbers while Lauderia borealis was the most important contributor to the pigment assessment: there was also a greater variety of mainly neritic species than in the very dense patch in the west. In the latter area near the edge of the continental shelf the dominant form was the neritic species Chaetoceros affinis (recorded as $C$. Schuettii by Gran, I9I2). These two areas were probably distinct in species and race composition (see above) as well as being separated by an area at a different stage in succession. Such indications as can be obtained from stramin net hauls suggest that a thinly populated area lies between the southern Irish coast and the area of high plant density near the edge of the continental shelf. ${ }^{\star}$ Species may have been transported there, perhaps from the south of Ireland as resting spores, or a wave of vegetative reproduction may have passed outwards, or resting spores may have been brought to the upper layers by vertical mixing which also provided the necessary rich supply of salts. In the middle of April I9Io the Michael Sars visited the same area and Gran found very dense phytoplankton to considerable depths associated with vertical mixing at the edge of the continental shelf; two stations to the east and nearer land had a less abundant phytoplankton, a further parallel to the conditions described here. Records of the repeated occurrence of two

\footnotetext{
* For this information I am indebted to Mr G. P. Farran.
} 

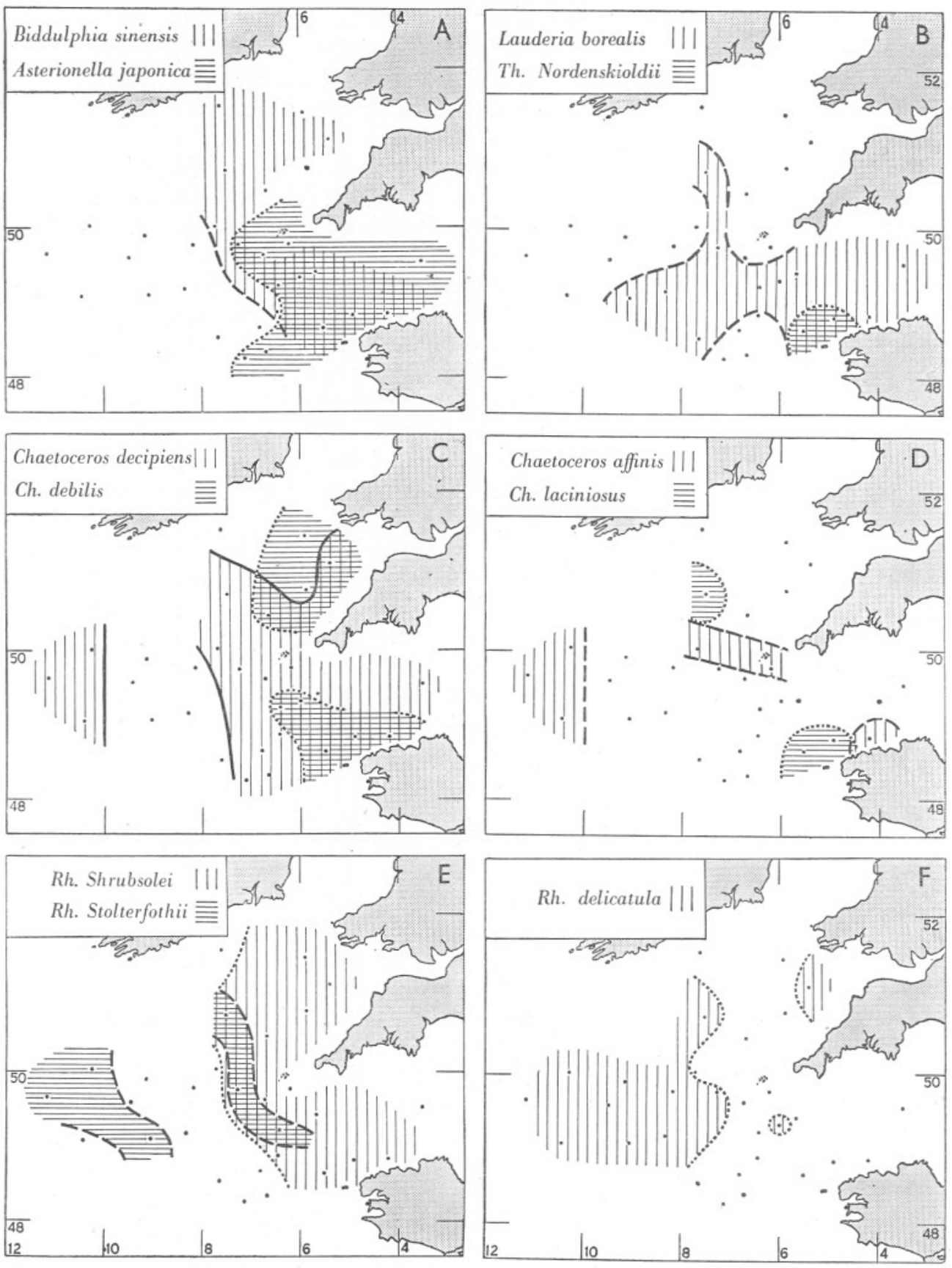

Fig. 5. Distribution of species found on the April cruise. The outer boundaries of neritic species are indicated by a broken line $(--$ or $\ldots .$.$) and the inner boundaries of species$ generally regarded as oceanic by a continuous line $(-)$ or by $(---)$. 

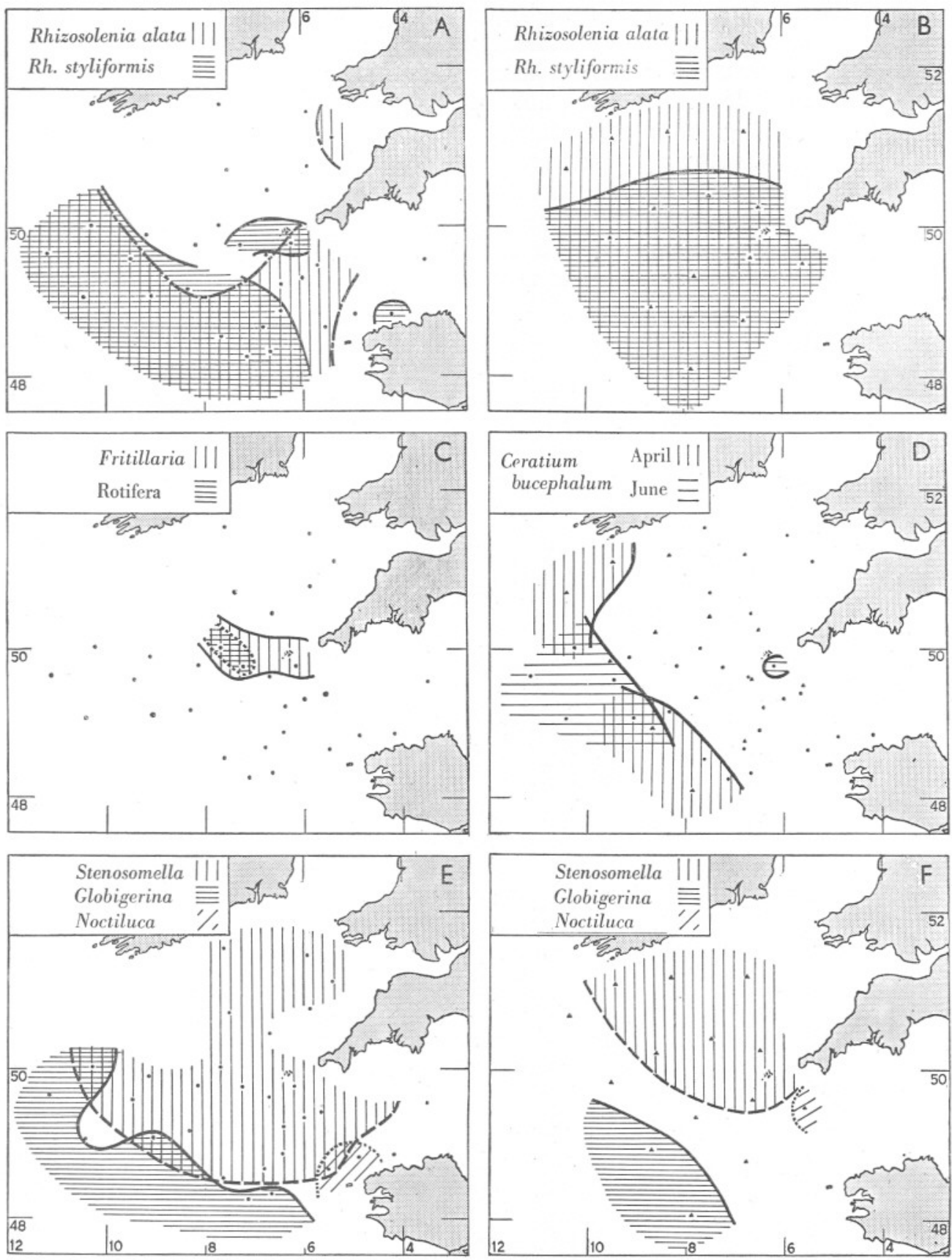

Fig. 6. Distribution of species found on the April cruise (A, C, D, E) and on the June cruise $(B, D, F)$. April stations are indicated by circular spots and June stations by triangles. 
separate maxima off the Norwegian coast, the outer associated with vertical mixing, are discussed and summarized by Gran (1929, I930). These April samples clearly confirm that the same phenomenon may occur in the southwestern area. It is noteworthy, however, that at the southern stations (9-I3), also near the edge of the continental shelf, no dense phytoplankton was found at the time of sampling. Perhaps zooplankton grazing had already reduced the standing crop.

The correlation between pigment units and numbers of cells is shown in Fig. 7A. The numbers of cells are unweighted for size: hence at St. 21, 37 and 5 where Chaetoceros species were dominant and St. 19-39 where Rhizo-

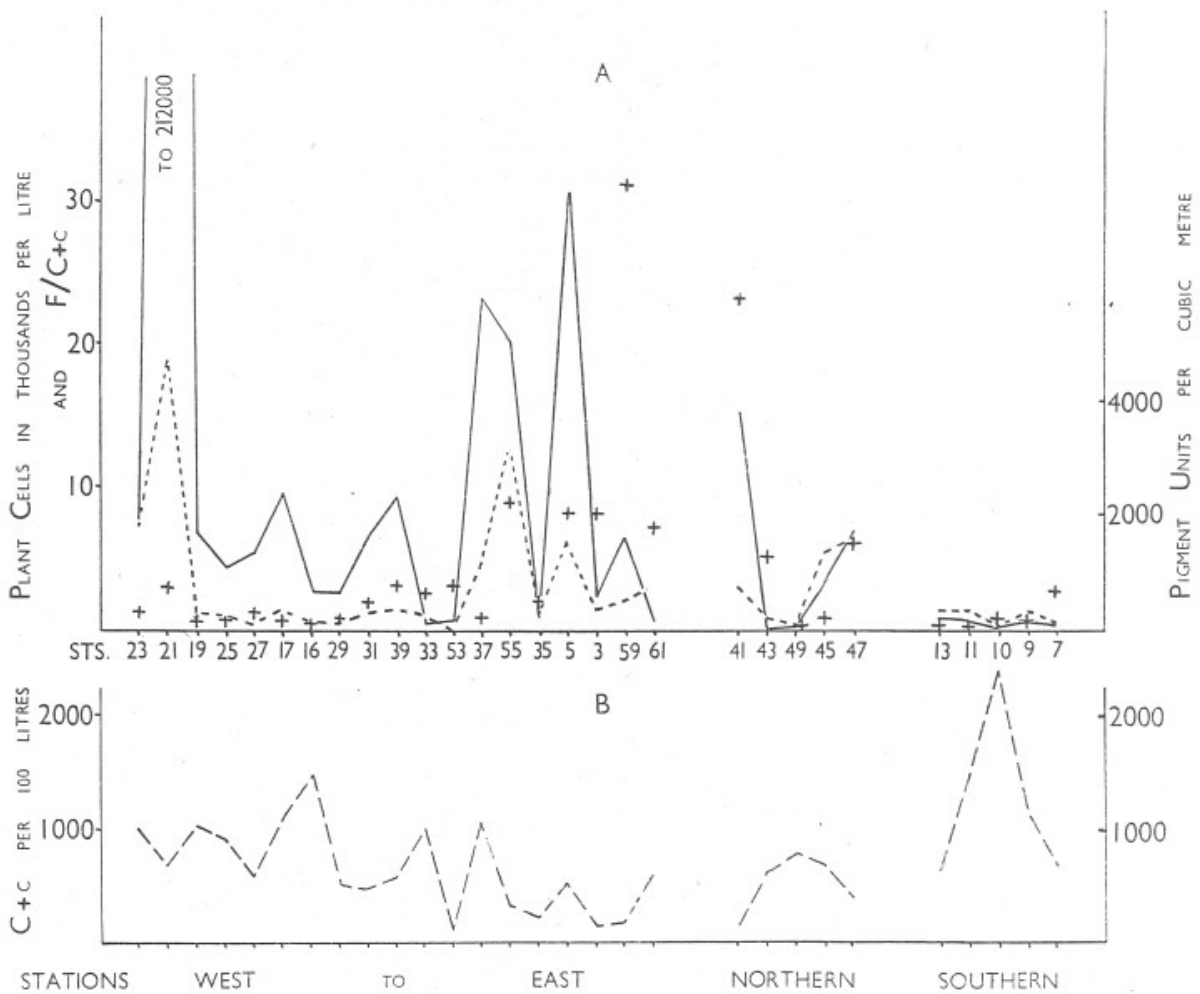

Fig. 7. Data from the April cruise in the south-western area. A, numbers of plant cells in thousands per litre of sea (continuous line), units of plant pigment per cubic metre (dotted line), and numbers of faecal pellets per copepod plus copepodite, $F / C+c(+)$. $\mathrm{B}$, numbers of copepods plus copepodites $(C+c)$ per Ioo 1 . of sea (broken line). Lines joining points have no real meaning.

solenia delicatula was dominant there is greatest divergence. At St. 7-I3 the large celled $R$. styliformis was dominant and hence, as may be seen from the graph, one pigment unit is equivalent to less than 4000 cells. Abnormally high pigment values may also arise from the extraction of pigment from abundant green faeces. The faecal pellets collected varied considerably in 
nature and size, nevertheless the ratio $F / C+c$ shows some correlation with the amount of available food. When cell numbers are low $F / C+c$ is also low, but there is no detailed correlation. In Fig. $7 \mathrm{~B}$ it is seen that the numbers of copepods plus copepodites show an inverse density relationship with the plant population between St. 23-6I and more definitely at St. 4I-47 and 7-I3.

The samples taken on the third cruise (June 2-7) are chiefly notable for the extreme scarcity of phytoplankton at most stations. This fact and the presence of abundant zooplankton, tingeing the acetone extract red or brown, made the assessment of colour difficult; Fig. 3 C is partly based on numbers of plant cells. The catch from which the pigment had been extracted was also examined for occurrence of species.

The mouth of the English Channel was again the area of highest cell numbers and greatest variety of species, which were mainly neritic. The central western and northern areas were again very sparsely populated with diatoms and dinoflagellates, but the zooplankton was rich (see Fig. 8). A rise

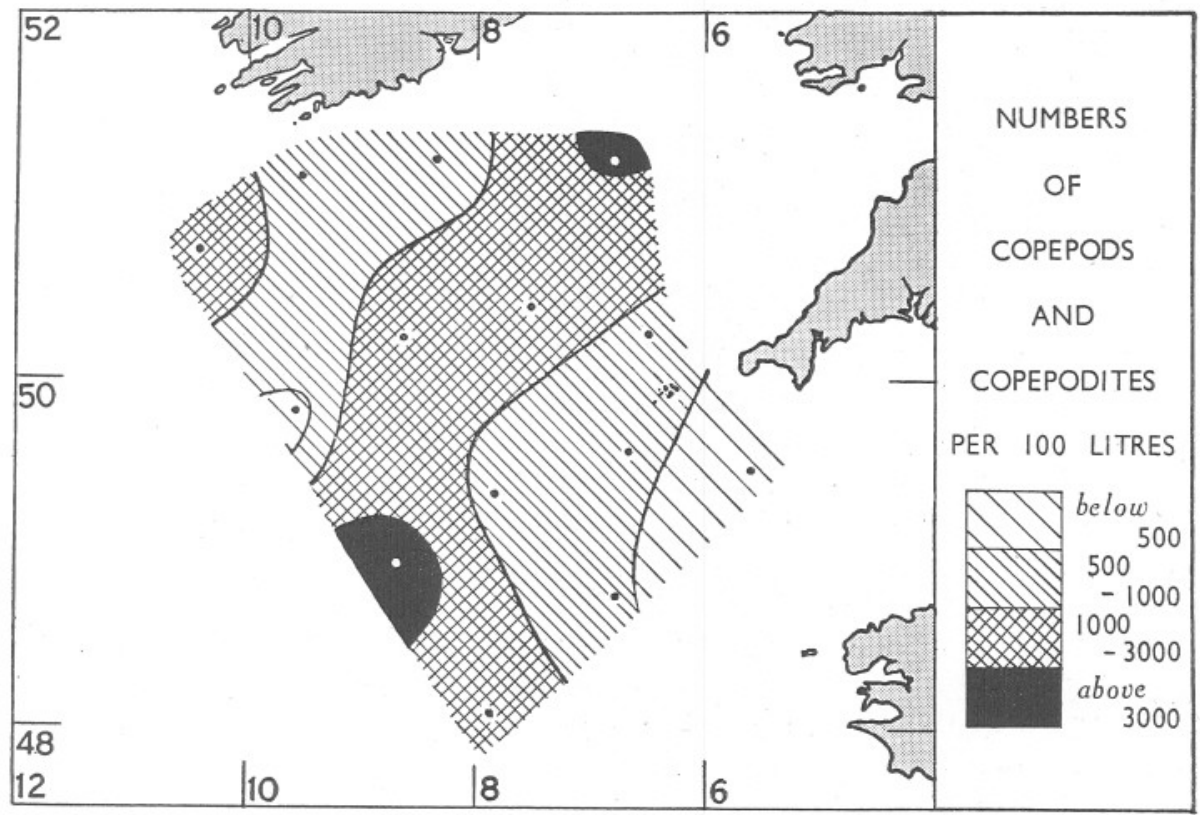

Fig. 8. The distribution of small copepods plus copepodites found on the June cruise in the south-western area.

in phytoplankton density was again found near the edge of the continental shelf. Rhizosolenia alata was present over the whole area and $R$. styliformis had spread further north and east, while Stenosomella ventricosa, a neritic tintinnid, appeared to have retreated north-eastward. Slight indications of more oceanic influence were seen at St. 6, 8 and I2 in the presence of Globigerina, Ceratium bucephalum, C. lamellicorne and Dinophysis tripos (D. homun- 
culus var. tripos in Ogilvie, I923). For charts of the distribution of some of these species see Fig. 6 B, D and F.

The faecal pellets were no longer green and the ratio $F / C+c$ was mainly below one, but it did not show detailed correlation with the low phytoplankton. The copepods plus copepodites as seen in Fig. 9 showed a reciprocal abundance with the plants at most stations, as is usually found at this time of the year.
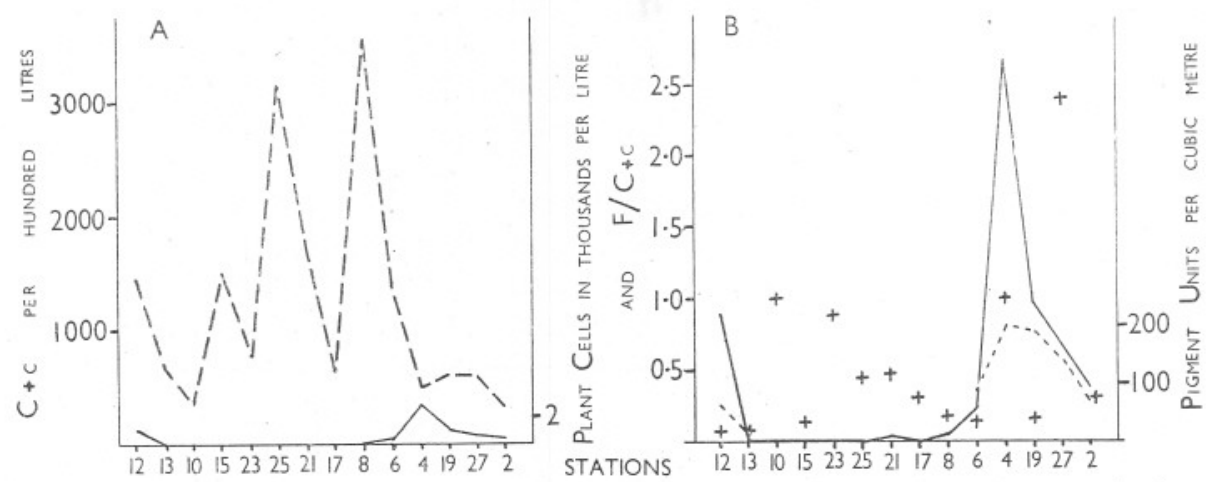

Fig. 9. Data from the June cruise in the south-western area. A, numbers of copepods plus copepodites $(C+c)$ per roo $\mathrm{l}$. (broken line) and the number of plant cells per litre (continuous line). The scales are similar to those used for the April data. B, numbers of plant cells per litre (continuous line), units of plant pigment per cubic metre (dotted line), and numbers of faecal pellets per copepod plus copepodite, $F / C+c(+)$. The vertical scale is magnified ten times. Lines joining points have no real meaning.

\section{OCCURRENCe AND Distribution of Various Species}

Chaetoceros species. The prominence of this genus in the spring maximum varies at Plymouth, and while in I934 it was poorly represented, in 1939 (a late year) it was very important. Similar variation in importance is seen at Sevenstones in unpublished records made by $\operatorname{Dr} M$. V. Lebour for the years 1913-17. In April 1939 members of the genus were abundant in all areas of dense phytoplankton (see Fig. 5C, D).

Biddulphia sinensis did not assume its usual prominence in the spring maximum at Plymouth, only appearing as rare in April and May. A few cells were found at the Channel mouth stations on the April and June cruises (see Fig. 5 A). In April 1938 it was abundant near the Lizard. Wulff has used this species as an indicator of Channel water in the southern North Sea (Wulff et al. 1934).

Phaeocystis globosa. No very dense patches have been found in the waters sampled in 1939. In April 1938 two patches were encountered, one with Biddulphia sinensis off the Lizard and the other west of the Channel mouth, about $8^{\circ} \mathrm{W}$.

Rhizosolenia delicatula. An unusual feature, both of the succession near Plymouth and of some of the stations of the April cruise, was the important part played by $R$. delicatula. Ostenfeld (I913) states that this species is 
"a temperate neritic species indigenous off the west coast of France, in the English Channel and in the southern part of the North Sea, where it is mostly found in the autumn". In the English Channel and Irish Sea it shows minor sporadic occurrences, usually being marked rare or very rare in available lists, and is often not recorded at all; it may occur in spring, summer or autumn, but May, October and November have the most records. Ogilvie (I923) found it to be fairly common in July off the south coast of Ireland, but only once was it recorded as very common (by Gough at Cardigan Bay Lightship in June and July I904). From the evidence available it is not possible to place it definitely in a sequence of species, but it seems usually to be a post-maximum species. Near Plymouth in 1939 it obviously filled the stage in succession immediately after the Chaetoceros outburst and was followed by $R$. Stolterfothii. It may very tentatively be suggested that the sparsely populated belt which it dominated in April between 8 and $10^{\circ} \mathrm{W}$. (see Fig. $5 \mathrm{~F}$ ) was at a later stage in succession than the more populous areas to east and west of it.

Rhizosolenia alata. Though this diatom apparently showed a stage in the penetration of an oceanic species up Channel in April (Fig. 6A) it must be noted that it had been present near Plymouth since February. Bygrave (I9II) found it usually more abundant on the north side of the Channel mouth than on the south, and it always seems to penetrate further into coastal waters than R. styliformis.

Ceratium species. Several members of this genus, C. tripos, C. macroceros, $C$. bucephalum and $C$. longipes have been designated by Wulff as indicators of Atlantic water coming from the north into the North Sea. C. tripos and C. macroceros were generally present in all parts of the south western region including Plymouth. C. longipes was not seen. C. bucephalum was this year present only at the outermost stations with the addition of St. 33 in association with particulariy oceanic forms (Fig. 6D). C. lamellicorne and also Dinophysis tripos (both southern species and rare in the samples) have likewise been found only at the outermost stations, though there are previous records of rare occurrences in the Channel mouth and at Plymouth.

Silicoflagellata. Distephanus speculum and Dictyocha fibula are oceanic and in the April samples showed a distribution similar to that of Rhizosolenia alata. Records in the Bulletin Planktonique show them to be scattered well up the Channel at all seasons. They are usually not caught in net hauls, so their presence probably indicated considerable abundance at the outer stations and at the mouth of the Bristol Channel; they may well have been present at a lower density over the whole of the area.

Globigerina. Only those stations are included in the distribution charts in which specimens showed long spines still attached (see Fig. 6E, F). They showed an outer distribution. Records in the Bulletin Planktonique show considerably more penetration up Channel. In April at St. 29 (mid-west region) very numerous dead shells, accompanied by much silt, probably indicated that there had been some upward movement of bottom water, but 
not necessarily at that point. Single damaged shells were found in the plankton at $\mathrm{L}_{4}$ on two occasions.

Noctiluca miliaris (see Fig. 6E, F). The distribution in April 1939 happens to be very similar to that recorded by Russell (1936, Fig. 2, p. 5 I0) and the species did not occur at Plymouth until July; it is possible that it had come from the south. However, in previous years, including 1934, it has shown sporadic outbursts on the north side of the Channel from early in the year.

ROTIFERA. Near Plymouth there was an outburst during April (see Fig. 2B), this was a little later than a similar one in I934. The patch of rotifers (neritic) with Fritillaria (oceanic) near the Scillies in April is suggestive of the mixed origin of the water there (see Fig. 6).

GASTROPOD LARVAE. Nearly all specimens collected on the cruises were very young pteropods of the genus Limacina. In April they showed an outer distribution and in June were present over practically the whole area. At Plymouth all specimens were dextral, i.e. gastropods other than pteropods, except a few very small ones at the end of the summer.

\section{Discussion}

Prior to a discussion of the distribution of species a short account of the hydrography of the region is necessary. Matthews (19I4) first suggested the existence of a cyclonic circulation in the south-western area, and drew attention to its probable biological importance. Harvey (1930) gives a general picture of the circulation at the mouth of the Channel, but emphasizes the variability of the system and the frequent occurrence of isolated patches of water at varying depths differing considerably in salinity from their surroundings. There is an inflow of water to the Channel which generally comes either from the south-west or from close to the French coast. Some high salinity water may pass north or north-west between the Scillies and Land's End; this water is joined by a variable quantity displaced out of the English Channel from eastward of the Lizard. Water coming from the Bristol Channel and from the Irish Sea is turned westward, and off the south coast of Ireland some of this is turned southward to join the eastward oceanic drift. A cyclonic circulation lying over the shallow continental plateau to the south of Ireland may thus be set up, but it is probably variable in extent and position. Russell (I939) connects it with the stable area of Sagitta elegans water in this region.

The salinity distributions at $5 \mathrm{~m}$. in April and June are shown in Fig. IO. In April the salinities and temperatures were similar at all depths, while in June there was indication at most stations of a thermocline above or below $25 \mathrm{~m}$.; vertical mixing was however particularly marked in the south at St. 6 . High salinity water lay to the west and south-west in the same region as the group of planktonic species indicating oceanic influence: Ceratium bucephalum, C. lamellicorne, Dinophysis tripos, Rhizosolenia styliformis, R. alata, Globigerina and silicoflagellates. Some of these species were recorded by Ogilvie (I923) in November I92I when there were other indications of Atlantic water reaching 

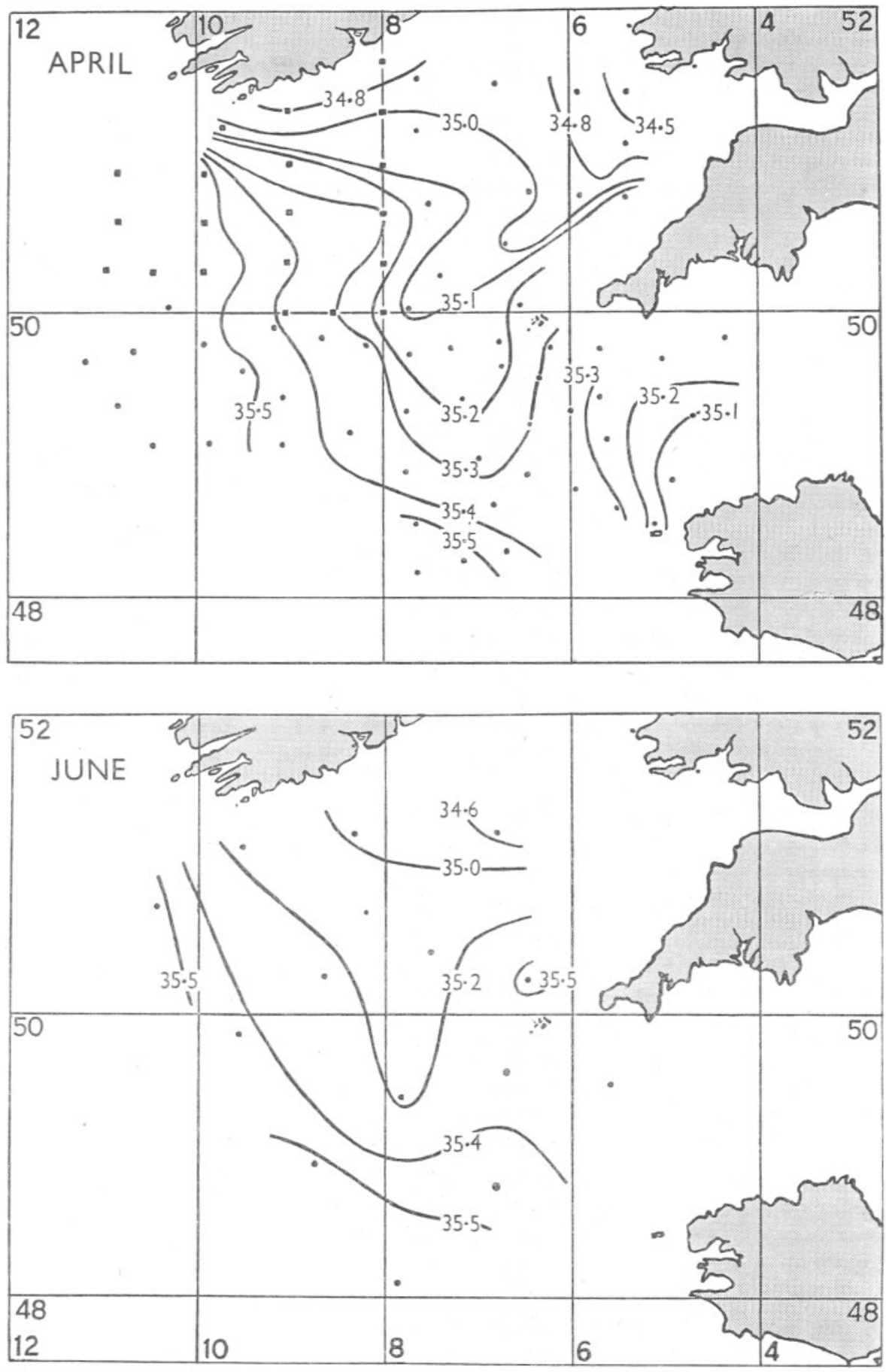

Fig. Io. Salinities in parts per thousand at $5 \mathrm{~m}$. below the surface found on the April and June cruises. Stations indicated by squares on the April chart are Irish stations sampled contemporaneously but at Io m. depth. Values at this depth differ very little if at all from those at the surface. 
almost to the south-eastern Irish coast. The presence in April of oceanic species, Ceratium bucephalum at St. 33 close to the Scillies and of Rhizosolenia styliformis and Fritillaria in that region, together with rotifers and other neritic species, is probably indicative of the mixture of oceanic and Channel water there. In June there was again a surface patch of high salinity water north of the Scillies but there were no particular species associated with it. Rhizosolenia styliformis was by no means confined to high salinity water; in June it had moved much further north-east and the presence of $R$. alata over the whole area in June and in April at the mouth of the Bristol Channel, accompanied by silicoflagellates, precludes their individual use as oceanic indicators.

It has been mentioned above that some neritic species show a north-west trend north of the Scillies; it is possible that this is associated with part of the cyclonic system, otherwise these samples do not show any clear indications of it. There is a wide distribution of neritic species and much overlapping of neritic and oceanic species, which is not surprising, as the swirl is of mixed oceanic and coastal water. The tongue of low salinity water coming south-west from the mouth of the Bristol Channel is well marked (as in 1938) and the position of the swirl at the time of sampling cannot be clearly defined. It is hoped that further information, concerning the distribution of biologically distinct water masses, will be forthcoming later from work on the macroplankton indicator species of the area (as listed by Russell, I939, pp. I79-8I). In any case, from the limited amount of material available and because of the need for extreme caution in the choice of indicators from among these rapidly reproducing forms, it is not yet justifiable to erect such indicator species in the microplankton.

With only three sets of samples taken at intervals of six weeks it is difficult fully to interpret the phytoplankton density data; it is given as a record of quantitative data obtained. It is interesting but difficult to compare satisfactorily the intensity of production near Plymouth with that in the denser areas in the west. The number of plant cells, 212,000 per litre, found in April at the edge of the continental shelf, is much in excess of those found at $\mathrm{L}_{4}$ and Rame (27,000 and 93,000 cells per litre respectively) but the units of plant pigment, 6250 and 4400 units, found in the dense western areas do not differ materially from the maximum values of approximately 7000 and 4000 recorded at $\mathrm{L}_{4}$ in 1933 and $\mathrm{I934}$. There is no proof, however, that any of these figures represent the actual peak value for the standing crop and it must always be remembered that in assessing the productivity of an area the duration for which dense phytoplankton occurs is very important, and that the standing crop, even at the peak, is only a small part of the production.

By making use of the Plymouth data on the seasonal succession of species and the time of the spring phytoplankton maximum, which it will be remembered was delayed until the middle of April, it is possible to elucidate to some extent the sequence of events in the south-western area. Data collected on the March cruise suggest that over the area sampled the diatom maximum had 
not then been reached; the oceanic stations were at an earlier stage in succession than those nearer the Channel. It is probable that the dense patches of phytoplankton found at the mouth of the Channel and near the edge of the continental shelf in the west (see Fig. 3B) in April were part of the spring maximum, while at St. 9-I3 near the edge of the continental shelf in the south the zooplankton (see Fig. 7B) had already depleted the standing crop. Possibly the mid-west zone ( $8-10^{\circ}$ W.) had by the time of sampling (April $18-20$ ) passed through a short maximal period. In June low midsummer conditions prevailed. In the middle of April 1938 a patch of "stinking water", indicating on that occasion the presence of abundant phytoplankton, was encountered in these latitudes between 8 and $9^{\circ} \mathrm{W}$. It is interesting to note that this otherwise barren mid-west region was that sampled by the Irish workers in I920-I at seven stations in a line between $5 \mathrm{I}^{\circ} 40^{\prime} \mathrm{N} ., 8^{\circ} 00^{\prime} \mathrm{W}$. and $49^{\circ} 20^{\prime} \mathrm{N}$., $8^{\circ} \circ 0^{\prime} \mathrm{W}$. The phytoplankton at the outer southern stations was sparse at all times of that period, and only moderately dense phytoplankton was sometimes found near the coast (Ogilvie, I923).

In April r938 Hickling investigated the distribution of phosphates in the south-western area. It is unfortunate that no phosphate estimations were made on the I939 cruises. As Hickling points out, high phosphate at this time of year may be due to large supplies reaching the area from vertical mixing with deep oceanic water in the extreme west, and possibly in the mouth of the English Channel, and from land drainage at the mouth of the Bristol Channel; low phosphate in the mid-west region was probably partly due to utilization by plants. Vertical circulation in the mid-west region may only involve mixing with rarely replenished bottom water. From the phytoplankton samples here reviewed the regions at the entrance to the English Channel, and to some extent at the mouth of the Bristol Channel, and also in the west at the edge of the continental shelf seem to be the most prolific. In particular the April phytoplankton density map shows considerable similarity with the surface distribution of phosphate found by Hickling (1938, Fig. I, p. I98). The low phytoplankton density in April at St. 9-I3 might be due to lack of mixing with deep waters at the edge of the continental shelf in the south or, as suggested above, to grazing.

It has been very tentatively suggested above that the mid-west region, dominated by Rhizosolenia delicatula in April, was at a later stage in succession than adjacent areas. This might be correlated with a poor supply of nutrient salts which would be expected to favour a rapid succession of species. Evidence from the phytoplankton mentioned by Hickling in 1938 does not run contrary to this interpretation. Only parts of the area usually thinly populated with plants had a rich zooplankton which might have been responsible for the small standing crop. Alternatively the $R$. delicatula community may have drifted eastwards from the rich zone near the edge of the continental shelf. If this mid-west region is occupied by part of the cyclonic swirl water, it is probably biologically older water than that to the east or west: it seems to be analogous 
to the "old" "offshore" water found by Sverdrup \& Allen (I939) off the Californian coast to be poor in diatoms. Basing his argument on the conditions of plankton production on the south and west coast of Iceland, Steemann Nielson (I937) stresses the importance of oceanic upwelling, drift of water masses and the age of the water and hence the time for development of a population of plants or animals, in offering an explanation of the relative abundance of phyto- and zooplankton; the considerations are equally applicable to the area here surveyed. As a very tentative hypothesis it is suggested ${ }^{\star}$ that the mouth of the English Channel is a main area of phytoplankton production, that much is converted to animal substance, green faeces and other forms of detritus, and as such is carried to the west by the swirl and consumed by the large animal population there; some of the dense production at the edge of the continental shelf in the west may be added to the system. Much more data is necessary before this idea can be put forward with any certainty.

\section{ACKNOWLEDGEMENTS}

I should like to express my gratitude to Mr P. G. Corbin and Mr G. A. Steven for taking the samples on the cruises and for the use of the data from the pigment extracts; and to Capt. Lord and the crew of the Salpa for taking the samples near Plymouth. Some of the salinity data was kindly supplied to the Marine Biological Association by the Fisheries Branch of the Department of Agriculture, Dublin, Eire. My thanks are also due to Dr M. V. Lebour for checking identifications of phytoplankton and allowing me to examine her Sevenstones data. I am particularly grateful to Mr F. S. Russell, F.R.S., Mr G. A. Steven, and Dr H. W. Harvey for their continual interest and helpful suggestions; Dr J. T. Hart kindly read the manuscript. The work was carried out at the Plymouth Laboratory while I was holding a Newnham College research studentship and a grant from the Department of Scientific and Industrial Research.

\section{SUMMARY}

A quantitative seasonal survey of the phytoplankton and small zooplankton has been made from the end of January to the end of August I939, at a station, $\mathrm{L}_{4}$, with supplementary observations at a station off Rame Head, both near Plymouth. The results are compared with those of a fuller survey made in I934.

The spring maximum in numbers of plant cells was late, not being reached until the middle of April.

The monthly means of the total numbers of animals caught were of the same order in the two years, but the numbers of copepods plus copepodites in I939 were only two-thirds of those in I934.

The numbers of faecal pellets per copepod plus copepodite again showed

* I am indebted to Mr F. S. Russell for the initial suggestion. 
correlation with the phytoplankton density, being greatest when plant food was most abundant; there were a few anomalies.

Similar samples were collected on cruises in March, April and June in an area west of the entrance to the English and Bristol Channels and to the westward as far as the edge of the continental shelf.

Charts are given of phytoplankton densities assessed by Harvey's pigment extraction method, and of species distribution.

The distribution of various species indicated more Atlantic influence at the stations to the west and south-west, and there was a spread of some of these species north-eastward between the April and June cruises. Some other distributions are very tentatively correlated with certain phases of the complex water circulation in this region.

For the most part the numbers of copepods plus copepodites showed inverse density relationships with the numbers of plants, and the number of faecal pellets per copepod plus copepodite indicated heaviest grazing at times and places of abundant plant food. There was no detailed correlation when both this ratio and the plant numbers were low; probably detritus then formed a larger proportion of the food.

Dense phytoplankton patches were found in April at the mouth of the English Channel, the Bristol Channel and at the edge of the continental shelf in the west: this distribution was similar to that of high surface phosphate recorded in April I938. The mid-west region ( $8-10^{\circ} \mathrm{W}$.) is usually thinly populated with plants. It is suggested that the mouth of the English Channel is an important plant productive region, possibly supplying a wider area. An effect of vertical mixing of surface with deep oceanic water at the edge of the continental shelf in increasing plant production is demonstrated in the west.

\section{REFERENCES}

Atkins, W. R. G., I930. Seasonal variations in the phosphate and silicate content of sea water in relation to the phytoplankton crop. Part V. Nov. I927 to April I929 compared with earlier years from 1923. Fourn. Mar. Biol. Assoc., Vol. XvI, pp. $82 \mathrm{I}-52$.

Bullen, G. E., I908. Plankton studies in relation to the western mackerel fishery. Fourn. Mar. Biol. Assoc., Vol. vili, pp. 269-302.

Bygrave, W., I9II. Report on the plankton of the English Channel in 1906. Mar. Biol. Assoc. Int. Fish. Invest. 3rd Report I906-8, pp. 235-68.

Cleve, P. T., I900. The Seasonal Distribution of Atlantic Plankton Organisms. Göteborg.

Gough, L. H., I905. Report on the plankton of the English Channel in 1903. Mar. Biol. Assoc. Int. Fish. Invest. Ist Report, I902-3, pp. 325-77.

1906. Plankton collected at the Irish light stations in 1904. Fisheries, Ireland, Sci. Invest. vI, pp. 227-79.

- 1907. Report on the plankton of the English Channel in 1904 and 1905. Mar. Biol. Assoc. Int. Fish. Invest. 2nd Report, I904-5, pp. 165-268.

Gran, H. H., I9I2. In Depths of the Ocean, Murray and Hjort, Chap. vi, p. 354.

I929. Investigation of the production of plankton outside Romsdalsfjord. I926-7. Rapp. Proc. Verb. Int. Cons. Explor. Mer., Vol. LVI, pp. I-II2. 
GRAN, H. H., I930. The spring growth of plankton at Møre in I928-9 and at Loføten in 1929 in relation to its limiting factors. Skrift. Norske Vidensk. Acad. Oslo, I Mat. Natur K1., No. 5.

HaRveY, H. W., I930. Hydrography at the mouth of the English Channel 1925-8. Fourn. Mar. Biol. Assoc., Vol. xvI, pp. 791-820.

1934. Measurement of phytoplankton population. Fourn. Mar. Biol. Assoc., Vol. xIX, pp. 76I-73.

Harvey, H. W., Cooper, L. H. N., Lebour, M. V. \& Russell, F. S., 1935. Plankton production and its control. Fourn. Mar. Biol. Assoc., Vol. xx, pp. 407-4I.

HICKLING, C. F., I938. The distribution of phosphates in the south-western area in April 1938. Fourn. Mar. Biol. Assoc., Vol. xxiII, pp. 197-200.

JørGensen, E., I927. Die Tierwelt der Nord- und Ostsee. Lief. viII, Teil II c $\mathrm{c}_{1}$ : Tintinnidae.

Kofoid, C. A. \& CAmpbell, A. S., I929. A conspectus of the marine and fresh water Ciliata belonging to the suborder Tintinnoinea.... Univ. Calif. Publ. Zool., Vol. xxxiv.

Lebour, M. V., I9I7. The microplankton of Plymouth Sound from the region beyond the breakwater. Fourn. Mar. Biol. Assoc., Vol. xI, pp. 133-82.

- 1925 . The Dinoflagellates of Northern Seas. Marine Biological Association.

- 1930. The Planktonic Diatoms of Northern Seas. Ray Society.

MatTHEWS, D. J., I9I4. The salinity and temperature of the Irish Channel and the waters south of Ireland. Fisheries, Ireland, Sci. Invest. I9I3. No. 4, pp. I-26.

OGILVIE, H. S., I923. Microplankton from the south coast of Ireland, June 1920Nov. I92I. Rapp. Proc. Verb. Cons. Int. Explor. Mer., Vol. xxix, Rapport Atlantique, 192I, pp. 30-7I.

OstenFeld, C. H., I9I3. Résumé des observations sur le plankton des mers explorées par le conseil pendant les années I902-8. Bacillariales. Cons. Int. Explor. Mer., Bulletin Trimestriel, Pt. 3, pp. 403-508.

- I93I. Résumé des observations sur le plankton des mers explorées par le conseil pendant les années 1902-8. Cons. Int. Explor.' Mer., Bulletin Trimestriel, Pt. 4, pp. 60I-72.

RuSSELL, F. S., 1936. Observations on the distribution of plankton animal indicators made on Col. E. T. Peel's yacht, St George, in the mouth of the English Channel, July 1935. Fourn. Mar. Biol. Assoc., Vol. xx, pp. 507-22.

_ I938. The Plymouth offshore medusa fauna. Fourn. Mar. Biol. Assoc., Vol. xxir, pp. 4 II -40 .

1939. Hydrographical and biological conditions in the North Sea as indicated by plankton organisms. Fourn. Cons. Int. Explor. Mer., Vol. xIv, No. 2, pp. I7I-92.

SteEMANN NiELSEN, E., I937. On the relation between quantities of phytoplankton and zooplankton in the sea. Fourn. Cons. Int. Explor. Mer., Vol. xII, No. 2, pp. I47-54.

SverDRUP, H. U. \& Allen, W. E., I939. Distribution of diatoms in relation to the character of water masses and currents off Southern California in 1938. Fourn. Mar. Research, Vol. II, No. 2, pp. I3I-44.

WULFF, A., BÜCKMANN, A. \& KÜNNE, CL., I934. Bericht über die Teilnahme an einer Fischereischutzfahrt der "Weser" zu Untersuchungen über die Verbreitung der Heringslarven in der südlichen Nordsee und dem Kanaleingang, 7. November bis I5. December 1933. Ber. Deutsch. Wiss. Komm. Meeresforsch., N.F., Bd. vII, Heft 3, pp. 328-42. 